\title{
Expression of insulin-like peptide 3 in the postnatal rat Leydig cell lineage: timing and effects of triiodothyronine-treatment
}

\author{
S M L C Mendis-Handagama ${ }^{1}$, H B S Ariyaratne ${ }^{1,2}$, L Mrkonjich $^{1}$ and R Ivell ${ }^{3}$ \\ ${ }^{1}$ Department of Comparative Medicine, The College of Veterinary Medicine, The University of Tennessee, Knoxville, \\ Tennessee 37996, USA, ${ }^{2}$ Department of Basic Sciences, Faculty of Veterinary Medicine and Animal Science, The \\ University of Peradeniya, Peradeniya, Sri Lanka and ${ }^{3}$ Research Centre for Reproductive Health, School of Molecular \\ and Biomedical Science, University of Adelaide, Adelaide, South Australia 5005, Australia
}

Correspondence should be addressed to S M L C Mendis-Handagama; Email: mendisc@utk.edu

\begin{abstract}
Fetal (FLC) and adult Leydig cells (ALC) secrete insulin-like peptide 3 (INSL3), which is linked to cryptorchidism in the newborn rat. Its gene regulation appears to be independent of that for most steroidogenic enzymes, and may thus be a marker for other aspects of ALC differentiation. Our study examined the following on INSL3 peptide expression in ALC lineage (i) timing, (ii) which cell stage, and (iii) effects of triiodothyronine (T3). Male Sprague-Dawley (SD) rats of postnatal days (pd) 1, 5, 7-21, 28, 40, 60, and 90 were used for the objectives (i) and (ii). For the objective (iii), control and T3-treated (daily T3 SC, $50 \mu \mathrm{g} / \mathrm{kg} \mathrm{bw)} \mathrm{SD} \mathrm{rats} \mathrm{of}$ pd7-16 and 21 were used. INSL3 was immunolocalized in Bouin's-fixed testes. FLC were positive and mesenchymal and Leydig progenitor cells were negative for INSL3 at tested ages. INSL3 in ALC lineage was first detected in newly formed ALC on pd16, although they were present from pd10. The intensity of INSL3 label was greater in ALC of pd40-90. ALC were present in T3-treated testes at pd9, but INSL3 first detected in them was on pd12. While INSL3 in FLC regulates testicular descent, INSL3 in ALC still has no well-defined function. However, its pattern of expression correlates temporally with the development of steroidogenic function and spermatogenesis. Thus, the delay between ALC differentiation and INSL3 expression in them implies that INSL3 in ALC is associated with maturation. The advancement of INSL3 expression in the ALC of T3-treated rats implies that this function is established earlier with T3-treatment.
\end{abstract}

Reproduction (2007) 133 479-485

\section{Introduction}

The peptide hormone insulin-like peptide 3 (INSL3), previously referred to as relaxin-like factor, or Leydig cell-derived insulin-like factor, is regarded as a marker for Leydig cells of the postpubertal testis in many species including human (Adham et al. 1993, Ivell et al. 1997). Based on the fact that the fetal Leydig cells (FLC) secrete INSL3 and testosterone in a gonadotropin-independent manner, INSL3 in rodents is considered to be developmentally regulated (Zimmermann et al. 1997). The role of INSL3 in the prenatal rodent testis is well established, being required for testicular descent (Nef and Parada 1999, Tomboc et al. 2000, Ivell and Bathgate 2002). Homozygous INSL3-deficient mice exhibit bilateral cryptorchidism, reflecting a crucial role for INSL3 during the first, transabdominal phase of testicular descent (Nef and Parada 1999, Zimmermann et al. 1999). In utero exposure of rats to di( $n$-butyl) phthalate (DBP) suppresses INSL3 gene expression, leading to cryptorchidism
(McKinnell et al. 2005). However, the role for INSL3 peptide in the postnatal testis is not well understood.

In the mouse testis, with the onset of puberty, INSL3 gene activity is strongly upregulated (Balvers et al. 1998, Spiess et al. 1999). Moreover, mature Leydig cells in the mouse produce INSL3 in a constitutive manner during adult life (Zimmermann et al. 1997, Balvers et al. 1998, Spiess et al. 1999). Research on the hypogonadal mouse, which lack functional gonadotropin production, has revealed that, at least in rodents, postnatal initiation of INSL3 production by the Leydig cells is luteinizing hormone (LH)-dependent (Balvers et al. 1998). These facts are also consistent with the observations on seasonal expression of INSL3 in the deer testis, which showed upregulation of INSL3 production is LH-dependent (Hombach-Klonisch et al. 2004).

Although in utero exposure of rats to DBP dramatically decreases the INSL3 gene expression in FLC, in utero exposure to flutamide has no effect (McKinnell et al. 2005). This latter observation suggests that INSL3 
expression in FLC is not androgen-regulated. INSL3 protein expression is reduced in Leydig cells of rats upon aging (Paust et al. 2002) and in roe deer during winter (Hombach-Klonisch et al. 2004); in both of these situations circulating $\mathrm{LH}$ levels are rather low, and supportive of the concept that INSL3 production in Leydig cells reflects the $\mathrm{LH}$-dependent differentiation status of the adult Leydig cell (ALC) in these circumstances. It is also reported that immunoexpression of INSL3 in Leydig cells of rats is strong on embryonic days 17.5 and 19.5 and after postnatal day 35, and weak during prepubertal ages (McKinnell et al. 2005). However, when precisely INSL3 is first expressed in the ALC lineage and in which cell stage of the lineage are information still unavailable in the literature; these issues are addressed in the present investigation.

The onset of the differentiation of ALC in the rat and mouse testes is independent of LH (Ariyaratne et al. 2000a, 2000b, 2000c, Baker et al. 2003). However, $\mathrm{LH}$ is required for the steps beyond the differentiation of Leydig stem cells to progenitor cells for further development and maturation of the progenitors to become mature ALC (Mendis-Handagama and Ariyaratne 2001). Thyroid hormone has a critical regulatory function on the onset of the differentiation of Leydig stem cells in the postnatal rat testis (Mendis-Handagama and Ariyaratne 2001). Arrest in the postnatal differentiation of ALC occurs under hypothyroid conditions in the prepubertal rat testis (Mendis-Handagama et al. 1998, Teerds et al. 1998, Ariyaratne et al. 2000b, 2000c) and following ethane dimethane sulfonate (EDS; kills Leydig cells in $48 \mathrm{~h}$ after administration) treatment in the adult rat testis (Ariyaratne et al. 2000d). Moreover, triiodothyronine (T3)-treatment in neonatal-prepubertal rats (Teerds et al. 1998, Ariyaratne et al. 2000c) and following EDStreatment in adult rats (Ariyaratne et al. 2000d) advances the onset of Leydig cell differentiation and results in increased numbers of Leydig cells per testis. However, these studies clearly state that although thyroid hormone is crucial for the onset of Leydig stem cell differentiation, $\mathrm{LH}$ and many other factors are essential for the stage beyond the onset of stem cell differentiation, which is maturation. There is no information on whether thyroid hormones have any effects on INSL3 production in Leydig cells of the postnatal testis in any mammalian species studied to date, including the rat. Therefore, in the present study, the effect of T3 on INSL3 expression in the adult population of Leydig cells in the rat testis was also investigated.

\section{Materials and Methods}

\section{Animals}

Male and female Sprague-Dawley rats were obtained from Harlan (Madison, WI, USA). They were paired ( $1: 1$ ) and housed in a single cage in the animal facility of The University of Tennessee College of Veterinary Medicine, under conditions of controlled temperature $\left(25^{\circ} \mathrm{C}\right)$ and lighting (14 h light:10 h darkness). Rats were provided food (Agway Prolab formula, Syracuse, NY, USA) and water ad libitum and were observed daily for litters. The day the pups were born was considered as day 1 of birth. Untreated male rats of 1, 5, 7-21, 28, 40, 60, and 90 days of age ( $n=5$ per group) and triiodothyronine (T3, Sigma; $50 \mu \mathrm{g} / \mathrm{kg}$ body weight)-treated rats (Ariyaratne et al. 2000c, 2000d) of days 7-16 and 21 days of age ( $n=5$ per group) were used.

\section{INSL3 antibody}

The anti-INSL3 antibody used in the immunocytochemical investigations of the present study was a polyclonal antibody raised in rabbits against the recombinant mouse INSL3 precursor. Details of the antibody are published elsewhere (Paust et al. 2002, Ivell et al. 2005).

\section{Collection and preparation of testis tissue}

Rats were euthanized by excess carbon dioxide and their testicles were removed, fixed by immersion in Bouin solution for 5-6 h. Fixed testis tissues were washed with $70 \%$ ethanol for several days until the yellow color (picric acid in Bouin solution) disappeared from the ethanol. Using an automated tissue processor (Tissue Tek, Miles Scientific, Cambridge, MA, USA), tissues were then processed through cycles of graded ethanols and xylene, infiltrated with, and then embedded in paraffin (Paraplast, Oxford Labware, St Louis, MO, USA). Paraffin-embedded testis tissue blocks were used to make $5 \mu \mathrm{m}$ sections using a Leitz microtome (three sections/testis). Tissue sections were adhered to ProbeOn Plus glass microscope slides (Fisher Scientific, Pittsburgh, PA, USA) to perform immunocytochemistry.

\section{Immunolocalization of INSL3 peptide in rat testes}

Paraffin wax in testis tissue sections was removed with xylene and rehydrated with decreasing concentrations of ethanols and brought in to deionized water. These sections were then washed in PBS $(\mathrm{pH} \mathrm{7.3)}$ for $5 \mathrm{~min}$ and incubated in 3\% hydrogen peroxide for $20 \mathrm{~min}$. Sections were then washed again in PBS and normal goat serum was added to tissues overnight $\left(4^{\circ} \mathrm{C}\right)$ to bind nonspecific proteins. The INSL3 antibody was used at a dilution in the ratio of 1:200 in streptavidin-peroxidase diluent (BioGenex, San Ramon, CA, USA) and incubated on tissue sections overnight at $4{ }^{\circ} \mathrm{C}$. Testis tissue sections used as negative controls were incubated with normal rabbit serum. INSL3 was detected using a commercially available biotin-streptavidin kit (BioGenex) according 
to the manufacturer's instructions. Sections were counterstained with Harris' hematoxylin, dehydrated with increasing concentrations of ethanol, brought to xylene and coverslipped using Permount. By performing the procedure thrice, repeatability of the results was confirmed.

\section{Results}

In the Leydig cell lineage of the adult population, INSL3 peptide was first detected at day 16 in newly formed ALC (Fig. 1A). The number of INSL3 positive cells in the testis interstitium increased with the advancement of age (Fig. 1A-F). The intensity of the INSL3 label was much greater in ALC at days 40,60, and 90 when compared with the younger ages tested (Fig. 1A-E). Fetal-type Leydig cells in the postnatal rat testis showed positive cytoplasmic labeling for INSL3 (Fig. 2A and B). The elongated spindle-shaped cells in the testis interstitium were negative for INSL3 for all ages tested in control and T3-treated rats (Figs 1-5).

The newly formed ALC in the testis interstium were easily distinguishable from peritubular mesenchymal cells/Leydig stem cells, progenitor cells and FLC, because they appear as small circular or polygonal profiles and initially not in clusters (Figs $1 \mathrm{~A}$ and $\mathrm{B}$ and $3 \mathrm{~A}$ and B). FLC usually appear as clusters of large circular profiles (Fig. 2A and B), surrounded by basal lamina components, which were evident in many of the sections (Fig. 2B). The peritubular mesenchymal cells and the progenitor cells could be easily identified because they are spindle-shaped (Figs 1-5). These newly formed ALC were present in the testis interstitium from postnatal day 10, but INSL3 peptide was not detected in them until postnatal day 16 (compare Fig. 3A and B); however, not all ALC at this age showed a positive label for INSL3 (Fig. 3B). In T3-treated rat testes, these newly formed ALC were first detected at day 9; however, they were not positive for INSL3 peptide on that day. The first detection of INSL3 epitopes in ALC of T3-treated rats was on postnatal day 12 (Fig. 4A), which is in contrast to the postnatal day 16 in control rats (Fig. 3B). The number of the ALC positive for INSL3 protein was greater in T3-treated rats when compared with the age-matched control rats at the tested ages (Figs $3 \mathrm{~B}$ and $4 \mathrm{~B}$ and $5 \mathrm{~A}$ and $B)$. Moreover, as shown in micrographs, labeling for INSL3 peptide was absent in some ALC whilst other ALC were positive for INSL3 (Figs 3 and 4). This heterogeneity for INSL3 labeling was mainly observed at younger ages (40 days and younger). Also, many seminiferous tubules of T3-treated rats showed evidence of a lumen and appeared at a more advanced stage of germ cell differentiation than the control rats (compare Figs $2 \mathrm{~A}$ and $B, 3 A$ and $B, 5 A$ and $B$ ).
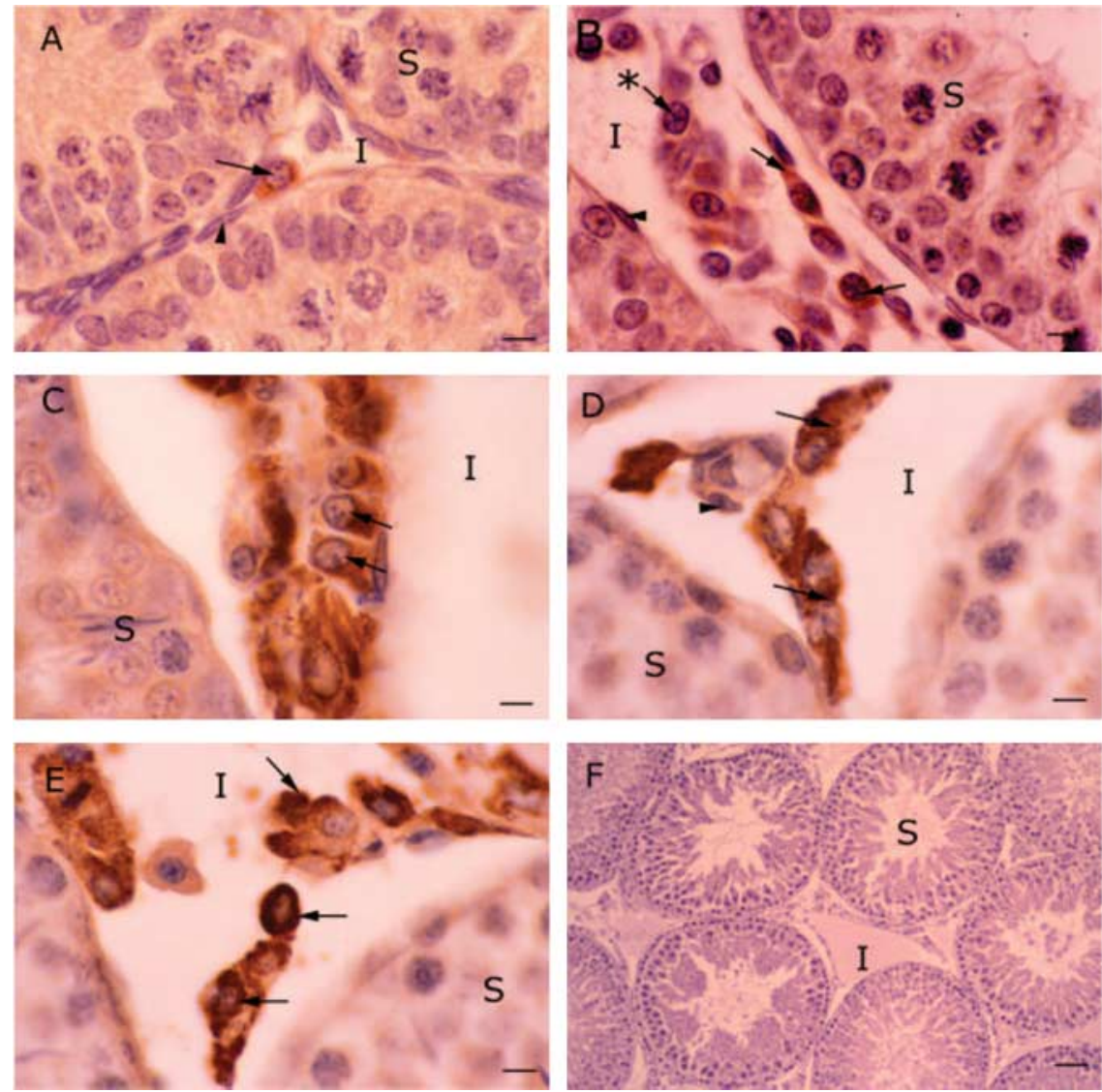

Figure 1 Representative testis tissue sections of postnatal rats of 16 (A), 21 (B), 40 (C), 60 (D), and $90(\mathrm{E})$ immunolabeled for INSL3 peptide. F, control incubations conducted with preimmune serum using 90-day-old rat testis tissue. Leydig cells immunopositive for INSL3 protein are depicted by arrows. A newly formed ALC in a 21-day-old testis, which is still not positive for INSL3 protein is shown with an arrow and asterisk $(*)$. Arrow heads depict spindle-shaped cells in the testis interstitium, which were negative for INSL3 peptide at all tested ages. S, seminiferous tubules; I, testis interstitium; and $\mathrm{bar}=4 \mu \mathrm{m}$ for $\mathrm{A}-\mathrm{E}$ and $28 \mu \mathrm{m}$ for $\mathrm{F}$. 

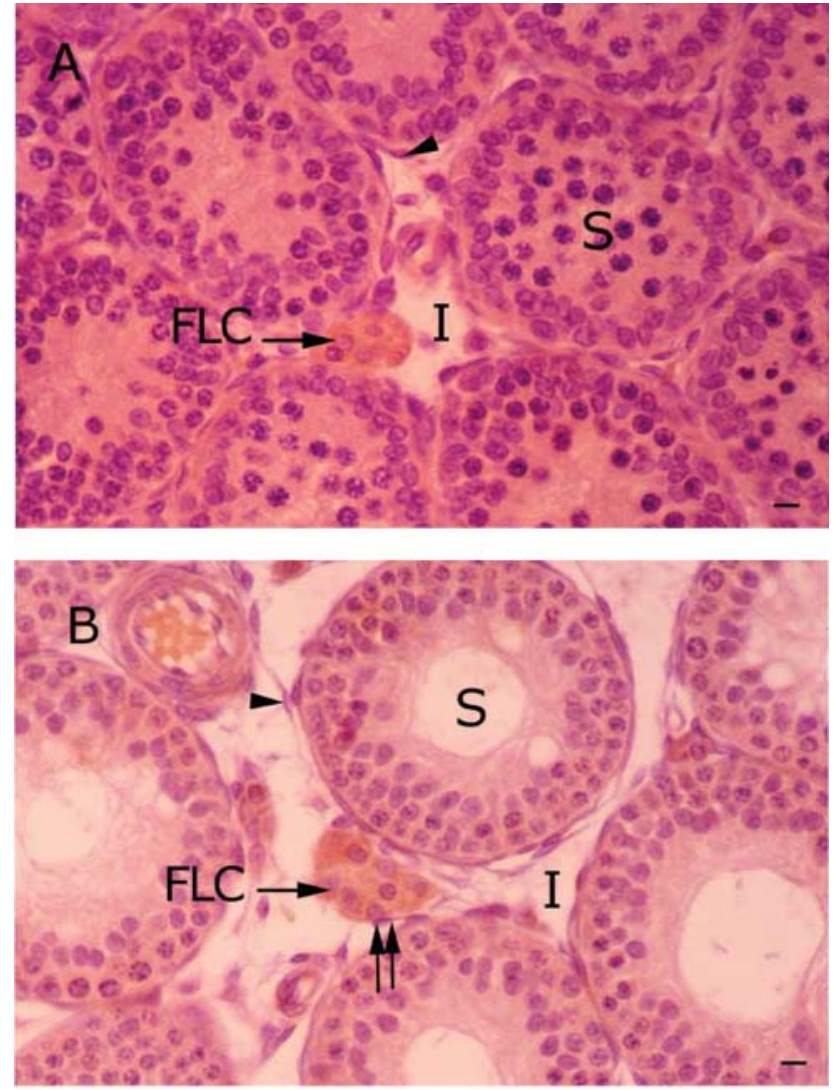

Figure 2 Representative testis tissue sections of control (A) and T3-treated (B) rats of 16 days of age. Fetal Leydig cells showed positive labeling for INSL3 peptide. FLC clusters are surrounded by basement membrane components (double arrows), which is evident in B. Seminiferous tubules in T3-treated rats (B) show a more advanced stage of germ cell differentiation with the presence of a lumen when compared with the controls (A). Elongated spindle-shaped cells in the testis intersitium are negative for INSL3 peptide (arrow heads).

$\mathrm{S}$, seminiferous cords/tubules; I, testis interstitium; and bar $=4 \mu \mathrm{m}$.

\section{Discussion}

Our objectives of the present study were threefold. The first two objectives were to examine the cell type and the timing of the first expression of INSL3 peptide in the ALC lineage in the rat testis. Our findings revealed that all spindle-shaped cell types in the testis interstitium, namely, endothelial cells, myoid cells, pericytes, mesenchymal cells, (peritubular and centrally positioned) and Leydig progenitor cells were negative for INSL3 peptide at all tested ages. We also demonstrated that the first detection of INSL3 peptide in the postnatal rat testis is on day 16 in newly formed ALC. To our knowledge, this is the first report to identify the cell type (i.e. newly formed $A L C$ ) and the timing of first expression of INSL3 peptide in the ALC lineage in any mammalian species studied to date, and specifically in the rat. It is also interesting to note that there is a time lag of 5 days between the first detection of this cell type in the postnatal rat testis interstium, which occurs on
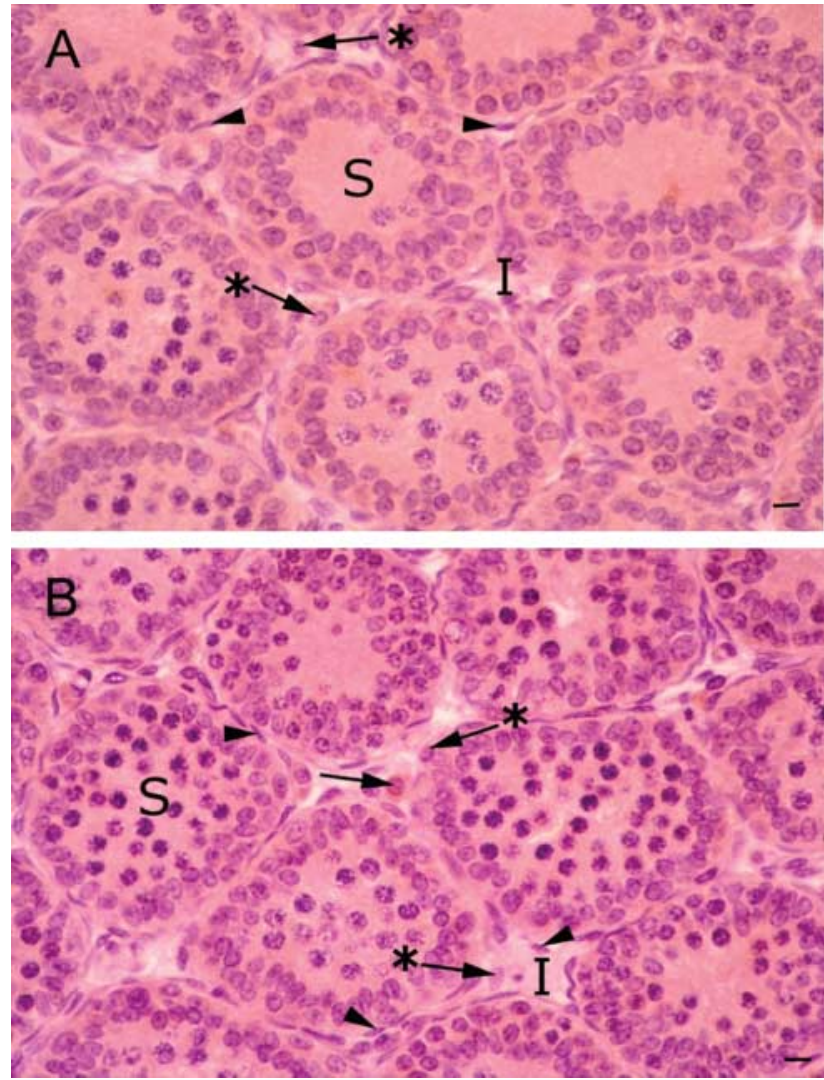

Figure 3 Representative testis tissue sections of 15-day control (A) and 16-day control (B) rats. Absence of labeling for INSL3 in newly formed ALC (arrows with asterisk) was seen on postnatal day 15 (A). Positive labeling for INSL3 (arrows) was first seen in newly formed ALC at postnatal day 16 in control rats (B). Elongated spindle-shaped cells in the testis intersitium were negative for INSL3 peptide (arrow heads). $\mathrm{S}$, seminiferous cords/tubules; I, testis interstitium; and bar $=4 \mu \mathrm{m}$.

postnatal day 10 (Mendis-Handagama et al. 1987, Ariyaratne et al. 2000a, 2000b, 2000c), and the first expression of INSL3 peptide in these cells. The unequivocal identification of the newly formed ALC in the testis interstitium of the prepubertal rat is relatively straightforward because of the characteristic morphology of these cells, as documented in previous studies (Mendis-Handagama et al. 1987, Ariyaratne and Mendis-Handagama 2000, Ariyaratne et al. 2000a, $2000 b, 2000 c)$. The newly formed ALC appear as circular profiles in the testis interstitium of tissue sections (Mendis-Handagama et al. 1987, Ariyaratne and Mendis-Handagama 2000, Ariyaratne et al. 2000a, $2000 b, 2000 c$ ) and therefore, can easily be distinguished from all spindle-shaped cells in the testis interstitium, which were mentioned above. Even at the light microscopic level, these newly formed adult Leydig cells are also easily distinguishable from the FLC, which are present in the prepubertal rat testis as clusters of large circular profiles (Mendis-Handagama et al. 1987, Ariyaratne and Mendis-Handagama 2000) surrounded 

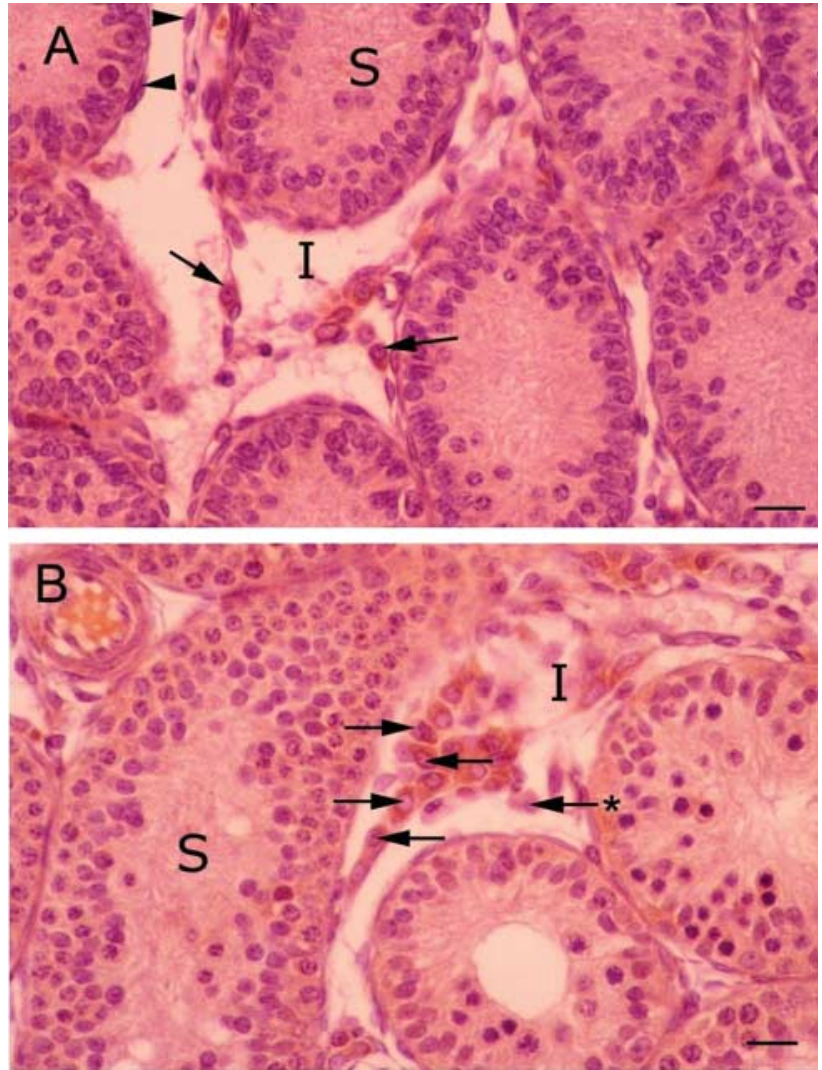

Figure 4 Representative testis tissue sections of T3-treated rats of 12 days (A) and 16 days (B). INSL3 was first seen in ALC on day 12 in T3-treated rats (A). There were many newly formed ALC (arrows) positive for INSL3 in T3-treated rats at day 16 (B) when compared with 16-day controls (compare with Fig. 3B). Arrows with asterisks depict ALC not positive for INSL3. Elongated spindle-shaped cells in testis intersitium were negative for INSL3 peptide (arrow heads). S, seminiferous cords/tubules; I, testis interstitium; and bar $=4 \mu \mathrm{m}$.

by basement membrane components, due to their smaller size and little or no cytoplasmic lipid.

Fetal Leydig cells were the only cell type in the testis interstitium, which were positive for INSL3 peptide in the rat testis from postnatal days $1-15$. The presence of FLC in the postnatal rat testis staining positively for INSL3 is in agreement with the study of McKinnell et al. (2005). However, we found that the labeling for INSL3 in FLC in the postnatal rat testis is not as weak as reported by McKinnell et al. (2005). It is possible that the duration of tissue fixation, which was $3 \mathrm{~h}$ in the study of McKinnell et al. (2005) and 5-6 h in the present study, the conditions of tissue processing, or the different antibody used, may have contributed to these differences in the two studies.

We never observed any spindle-shaped cells in the testis interstitium to be positive for INSL3 peptide at any stage. As the concentration of INSL3 in Leydig cells is considered to reflect their functional status (Foresta et al. 2004), the time lag observed between the first appearance of the newly formed ALC in the prepubertal rat
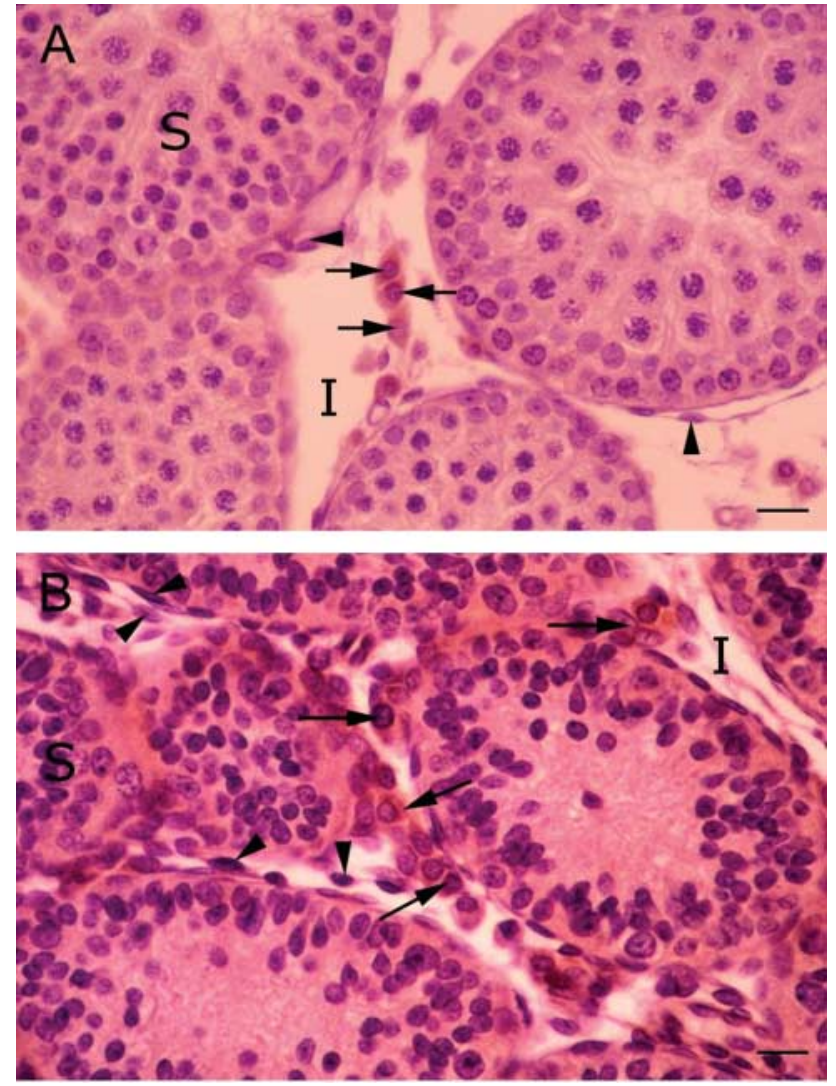

Figure 5 Representative testis tissue sections of 21-day control (A) and T3-rats (B). There were many ALC (arrows) positive for INL3 in T3-treated rats (B) when compared with controls (A). Elongated spindleshaped cells in testis intersitium were negative for INSL3 peptide (arrow heads). Seminiferous cords/tubules in T3-treated rats (B) showed a more advanced stage of germ cell differentiation with the presence of a lumen when compared with the controls of the same age (A). $\mathrm{S}$, seminiferous cords/tubules; I, testis interstitium; and bar $=4 \mu \mathrm{m}$.

testis and the first detection of INSL3 peptide suggests that the functional role of INSL3 in ALC does not begin immediately upon their appearance in the testis interstium, i.e. at the onset of stem cell differentiation or progenitor cell stage. This is reminiscent of what we observed with anti-Mullerian hormone receptor type II (AMHRII) protein expression in cells of Leydig lineage (Mendis-Handagama et al. 2006); however, AMHRII is detected in newly formed ALC on postnatal day 13, which is 3 days prior to INSL3 peptide. Moreover, the increase in the positive immunolabeling density for INSL3 in Leydig cells with age, especially from 40 to 90 days of age is also reminiscent of what is observed with AMHRII expression in these cells (Mendis-Handagama et al. 2006). These findings fit with the concept that the concentrations of INSL3 peptide and also AMHRII protein in Leydig cells are indeed reflections of their functional status.

Our third objective was to test the effects of T3-treatment of neonatal-prepubertal rat on the expression of INSL3 peptide in the ALC lineage. Triiodothyronine-treatment 
in neonatal-prepubertal rats (Teerds et al. 1998, Ariyaratne et al. 2000c) and following EDS-treatment in adult rats (Ariyaratne et al. 2000d) advances the onset of Leydig cell differentiation and results in increased numbers of Leydig cells per testis. In the present study, T3-treatment caused a reduction in the time lag between the first detection of the newly formed ALC, as shown previously (Ariyaratne et al. 2000c), and also the presence of INSL3 peptide in them 3 days after their first appearance, compared with untreated controls, which had a time lag of 6 days. This finding is also reminiscent of what is seen with plateletderived growth factor-A protein (PDGF-A) expression in cells of Leydig lineage, as T3-treatment caused a reduction in the time lag between the first appearance of $\mathrm{ALC}$ and the first detection of PDGF-A in them (Fecteau et al. 2006). The observations of the present study suggest that the role of INSL3 in the cells of Leydig lineage is established in half the duration or faster following T3-treatment when compared with the controls.

It has also been observed that culture of isolated Leydig cells from sexually mature rats with $\mathrm{T} 3$ resulted in stimulated secretion of testosterone and estrogen under basal conditions as well as in response to $\mathrm{LH}$-stimulation (Maran et al. 2000). Additionally, T3-treatment of mouse Leydig cells coordinately augmented the levels of steroidogenic acute regulatory (StAR) protein and StAR mRNA, and steroid production (Manna et al. 1999, $2001 a, 2001 b)$. StAR protein is involved in the intracellular cholesterol transport mechanism during LH-stimulated steroidogenesis in Leydig cells (Stocco 1996). Therefore, it appears likely that T3 has accelerated the establishment of steroidogenic function in ALC. This suggestion is also supported by the fact that the seminiferous tubules of T3-treated rats were at a more advanced stage of development when compared with age-matched controls up to 21 days, possibly due to more androgen availability following T3-treatment. If the first detection of INSL3 peptide in newly formed ALC is an indication of the functional maturation of the ALC population, T3-treatment appears to accelerate the mechanisms involved in the maturation of these cells by reducing the time by $50 \%$ when compared with controls.

LH stimulates testosterone and INSL3 production by the Leydig cells during development in vivo. Human studies conducted with treatments of different combinations of hormones of the hypothalamo-hypophyseal-testicular axis have suggested that the production of INSL3 is linked to the status of that axis (Foresta et al. 2004). However, it is also reported that INSL3 secretion is dependent on the chronic differentiating effect of $\mathrm{LH}$ on Leydig cells but independent of the acute steroidogenic LH-mediated action (Sadeghian et al. 2005). Thus, even though testosterone and INSL3 are both dependent on $\mathrm{LH}$, these two Leydig cell hormones appear to be regulated differently (Bay et al. 2005).
Six days into the maturation towards the next cell stage of the lineage, the newly formed ALC in the postnatal rat testis express INSL3 peptide for the first time in their lineage. This observation coincides with the gradual rise in circulating LH levels at this time, which are rather low at the time of the onset of Leydig stem cell differentiation in the rat (Lee et al. 1975). It is also interesting to note that receptors for $\mathrm{LH}$ have been first detected in the ALC lineage on postnatal days 11 and 12 in control and T3-treated rats respectively, (Ariyaratne et al. 2000c), being 3-4 days prior to the detection of INSL3 peptide.

If INSL3 production in the postnatal Leydig cells is LH-dependent, it is possible that the first detection of INSL3 in newly formed ALC at postnatal day 16 may be an indication of the progression of the functional maturation of the ALC population, which occurs faster (reducing the time taken since their appearance in the testis interstitium by $50 \%$ ) in T3-treated rats. Based on the findings of the present investigation, we suggest that the expression of INSL3 peptide in the ALC lineage reflects a milestone in their differentiation process, and may be one the indications of their functional maturation for androgen production.

\section{Acknowledgements}

Thanks to Greg Hirshoren of the Instructional Resources of the UTCVM for his assistance in preparation of the color photograph plates shown in this paper. Supported by: World Health Organization, The University of Tennessee Center of Excellence and the Professional Development Award program. The authors declare that there is no conflict of interest that would prejudice the impartiality of this scientific work.

\section{References}

Adham IM, Burkhardt E, Benahmed M \& Engel W 1993 Cloning of a cDNA for a novel.insulin-like peptide of a testicular Leydig cells. Journal of Biological Chemistry 268 26668-26672.

Ariyaratne HBS \& Mendis-Handagama SMLC 2000 Changes in the testis interstitium of Sprague-Dawley rats from birth to sexual maturity. Biology of Reproduction 62 680-690.

Ariyaratne HBS, Mendis-Handagama SMLC, Hales DB \& Mason JI 2000a Studies on the onset of Leydig precursor cell differentiation in the prepubertal rat testis. Biology of Reproduction 63 165-171.

Ariyaratne HBS, Mason JI \& Mendis-Handagama SMLC 2000b Effects of tri-iodothyronine on testicular interstitial cells and androgen secretory capacity of the prepubertal rat. Biology of Reproduction 63 493-502.

Ariyaratne HBS, Mason JI \& Mendis-Handagama SMLC 2000c Effects of thyroid and luteinizing hormones on the onset of precursor cell differentiation into Leydig cells in the prepubertal rat testis. Biology of Reproduction 63 898-904.

Ariyaratne HBS, Mills N, Mason JI \& Mendis-Handagama SMLC 2000d Thyroid hormone and Leydig cell regeneration in the adult rat following ethane dimethane sulphonate treatment. Biology of Reproduction 63 1115-1123.

Baker PJ, Johnston H, Abel M, Charlton HM \& O'Shaughnessy PJ 2003 Differentiation of adult-type Leydig cells occurs in gonadotrophindeficient mice. Reproductive Biology and Endocrinology 1 4-12. 
Balvers M, Spiess AN, Domagalski R, Hunt N, Kilie E, Muhopadhyay A, Hanks E, Charlton HM \& Ivell R 1998 Relaxin-like factor expression as a marker of Differentiation in the mouse testis and ovary. Endocrinology 139 2960-2970.

Bay K, Hartung S, Ivell R, Schumacher M, Jurgensen D, Jorgensen N, Holm M, Skakkeback NE \& Andersson AM 2005 Insulin-like factor 3 serum levels in normal men and 85 men with testicular disorders:relationship to the luteinizing hormone-testosterone axis. Journal of Clinical Endocrinology and Metabolism 90 3410-3419.

Fecteau KA, Mrkonjich L, Mason JI \& Mendis-Handagama SMLC 2006 Detection of platelet-derived growth factor-A (PDGF-A) protein in cells of Leydig lineage in the postnatal rat testis. Histology and Histopathology 21 1295-1302.

Foresta C, Bettella A, Vinanzi C, Dabrilli P, Meriggiola MC, Garolla A \& Ferlin A 2004 A novel circulating hormone of testis origin in humans. Journal of Clinical Endocrinology and Metabolism 89 5952-5958.

Hombach-Klonisch S, Schoen J, Kehlen A, Blottner S \& Klonisch T 2004 Seasonal expression of INSL3 and Lgr8/Insl3 receptor transcripts indicates variable differentiation of Leydig cells in the roe deer testis. Biology of Reproduction 71 1079-1087.

Ivell R \& Bathgate R 2002 The reproductive biology of the relaxin-like factor (RLF/INSL3). Biology of Reproduction 67 699-705.

Ivell R, Balvers M, Domagalski R, Ungerforen H, Hunt N \& Schulze W 1997 Relaxin-like factor: a highly specific and constitutive new marker for Leydig cells in the human testis. Molecular Human Reproduction 3 459-466.

Ivell R, Hartung S \& Anand-Ivell R 2005 Insulin-like factor 3 (INSL3) where are we now? Annals of the New York Academy of Sciences 1041 486-496.

Lee VK, de Kretser DM, Hudson B \& Wang C 1975 Variation in serum $\mathrm{FSH}, \mathrm{LH}$ and testosterone levels in male rats from birth to sexual maturity. Journal of Reproduction and Fertility 29 261-269.

Manna PR, Tena-Sempere M \& Huhtaniemi IT 1999 Molecular mechanisms of thyroid hormone stimulated steroidogenesis in mouse Leydig tumor cells. Journal of Biological Chemistry $\mathbf{5}$ 909-5918.

Manna PR, Roy P, Clark BJ, Stocco DM \& Huhtaniemi IT 2001a Interaction of thyroid hormone and steroidogenic acute regulatory (StAR) protein in the regulation of murine Leydig cell steroidogenesis. Journal of Steroid Biochemistry and Molecular Biology $\mathbf{7 6}$ 167-177.

Manna PR, Kero J, Tena-Sempere M, Pakarinan P, Stocco DM \& Huhtaniemi IT 2001b Assessment of mechanisms of thyroid hormone action in mouse Leydig cells: regulation of the steroidogenic acute regulatory protein, steroidogenesis and luteinizing hormone receptor function. Endocrinology 14 319-331.

Maran RR, Arunakaran J \& Aruldhas MM 2000 T3 directly stimulates basal and modulates $\mathrm{LH}$ induced testosterone and oestradiol production by rat Leydig cells in vitro. Endocrine Journal 4 417-428.

McKinnell C, Sharpe RM, Mahood K, Hallmark N, Scott H, Ivell R, Staub C, Jegou B, Haag F, Koch-Nolte F \& Hartung S 2005 Expression of insulin-like factor 3 protein in the rat testis during fetal and postnatal development and in relation to cryptorchidism induced by in utero exposure to di ( $n$-Butyl) phthalate. Endocrinology 146 4536-4544.

Mendis-Handagama SMLC \& Ariyaratne HBS 2001 Differentiation of the adult Leydig cell population in the postnatal testis. Biology of Reproduction 65 660-671.

Mendis-Handagama SMLC, Ariyaratne HBS, Teunissen van Manan KR \& Haupt RL 1998 Differentiation of adult Leydig cells in the neonatal rat testis is arrested by hypothyroidism. Biology of Reproduction $\mathbf{5 9}$ 344-350.

Mendis-Handagama SMLC, Ariyaratne HBS, Di Clemente N \& Mrkonjich L 2006 Detection of anti mullerian hormone receptor type II in cells of the rat testis interstitium from birth to sexual maturity. Histology and Histopathology 21 125-130.

Mendis-Handagama SMLC, Risbridger GP \& de Kretser DM 1987 Morphometric analysis of the components of the neonatal and adult rat testis interstitum. International Journal of Andrology 10 525-534.

Nef S \& Parada LF 1999 Cryptorchidism in mice mutant for Insl3. Nature Genetics 22 295-299.

Paust HJ, Wessels J, Ivell R \& Mukhopadhyay AK 2002 The expression of the RLF/INSL3 gene is reduced in Leydig cells of the aging rats. Experimental Gerontology 37 1459-1465.

Sadeghian H, Anand-Ivell R, Balvers M, Relan V \& Ivell R 2005 Constitutive regulation of the Ins/3 gene in rat Leydig cells. Molecular and Cellular Endocrinology 241 10-20.

Spiess AN, Balvers M, Tena-Sempere M, Huhtaniemi I, Parry L \& Ivell R 1999 Structure and expression of the rat relaxin-like factor (RLF) gene. Molecular Reproduction and Development 54 319-325.

Stocco DM 1996 Acute regulation of Leydig cell steroidogenesis. In The Leydig Cell, pp 241-258. Eds AH Payne, MP Hardy \& LD Russell. Vienna, IL: Cache River Press.

Teerds KJ, de Rooij DG, de Jong FH \& van Haaster LH 1998 Development of the adult type Leydig cells cell population in the rat is affected by neonatal thyroid hormone levels. Biology of Reproduction 59 344-350.

Tomboc M, Lee PA, Mitwally MF, Schneck FX, Bellinger M \& Witchell SF 2000 Insulin-like 3/Relaxin-like factor gene mutations are associated with cryptorchidism. Journal of Clinical Endocrinology and Metabolism 85 4013-4018.

Zimmermann S, Schotler P, Engel W \& Adham IM 1997 Mouse Leydig insulin-like (Ley I-L) gene: structure and expression during testis and ovary development. Molecular Reproduction and Development 47 30-38.

Zimmermann S, Steading G, Emmen JMA, Brinkmann AO, Nayemia K, Holstein AF, Engel W \& Adham IM 1999 Targeted disruption of the Insl3 gene causes bilateral cryptorchidism. Molecular Endocrinology 13 681-691.

Received 29 September 2006

First decision 30 October 2006

Accepted 13 November 2006 